\title{
Wszechstronność upodobań kulinarnych. 0 dystynktywnych i komunikacyjnych właściwościach jedzenia
}

DOI: 10.19195/2083-7763.9.11

\section{Wprowadzenie}

Pozycja społeczna jako czynnik kształtujący wybory kulturowe co najmniej od czasów T. Veblena ${ }^{1}$ stanowi tradycyjny przedmiot socjologicznych dociekań. Współczesna odsłona tej problematyki dotyczyła głównie pytania o aktualność analiz klasowych w opisywaniu i wyjaśnianiu zróżnicowań kulturowych a także tego, według jakich osi społecznej strukturalizacji przebiega to zróżnicowanie i w jaki sposób się przejawia (czy dotyczy jawnych zachowań, czy też raczej subtelności stylu i sposobów praktykowania wyborów) ${ }^{2}$. W tym kontekście stawiano tezę o wyłanianiu się nowych form kapitału kulturowego czy też nowych wzorów dystynkcji klasowych, w których upodobanie do „młodszej” i mniej skanonizowanej kultury (seriale, gry wideo, muzyka popularna) lub też otwartość na to, co nowe, ekscytujące i „egzotyczne” (swoisty kosmopolityzm) wypierają tradycyjne, „uświęcone” znaczniki wysokiego statusu (związane z kulturą prawomocną) $)^{3}$. Niewątpliwie jednym $z$ centralnych zagadnień $w$ tej debacie

${ }^{1}$ T. Veblen, Teoria klasy próżniaczej, przeł. J. Frentzel-Zagórska, Warszawa 2008.

2 D.B. Holt, Does cultural capital structure American consumption?, "Journal of Consumer Research" 25, 1998, nr 1, s. 1-25; M. Cebula, Społeczne uwarunkowania gustów i praktyk konsumpcyjnych. Zbieżność pozycji społecznych i stylów życia czy autonomizacja kultury?, „Studia Socjologiczne” 209, 2013, nr 2, s. 97-125; T.W. Chan, J.H. Goldthorpe, Social Stratification and Cultural Consumption: Music in England, „European Sociological Review” 23, 2007, nr 1, s. 1-19.

3 A. Prieur, M. Savage, Updating cultural capital theory: A discussion based on studies in Denmark and in Britain, „Poetics” 39, 2011, nr 6, s. 566-580. 
jest teza o „wszystkożerności” (omniworyzmie), wprowadzona do naukowego dyskursu przez Richarda A. Petersona i współpracowników ${ }^{4}$. Jej podstawą jest empiryczna obserwacja, że w społeczeństwach nowoczesnych (głównie zachodnich) stratyfikacja kulturowa przybiera kształt odwróconej piramidy, której krawędź górna (klasycznie podstawa) symbolizuje szerokość gustów i praktyk klasy wyższej, skłonnej w swoich wyborach łączyć to, co tradycyjnie „wysokie” (na przykład muzyka poważna) z tym, co przynależne kulturze masowej czy popularnej (jak muzyka pop czy rock), a wierzchołek odpowiada gustowi klas niższych, zawężonemu do tego, co najbardziej spopularyzowane. Ten model stratyfikacji otwarcie przeciwstawia się wizji podziałów klasowych utrwalonej przez teorię kultury masowej. Podział na „elity i masy” zostaje zastąpiony podziałem na konsumenta „Wszystko-, , i „jednożernego”.

Mimo szerokiego potwierdzenia tezy o „wszystkożerności” w dziesiątkach badań socjologicznych ${ }^{5}$ (także polskich ${ }^{6}$ ) natura tego zjawiska wciąż nie doczekała się jednolitej interpretacji teoretycznej ${ }^{7}$. Z jednej strony spotykamy koncepcje sugerujące, że szeroka partycypacja w kulturze świadczy o rozmywaniu się tradycyjnych hierarchii smaków i klarownych kodów komunikujących miejsce w przestrzeni społecznej, przez co niemożliwe staje się odczytanie, jaka kultura jest nadrzędna oraz kto do niej przynależy ${ }^{8}$. Otwiera to pole do redefinicji roli gustów i praktyk jako sfery indywidualnej ekspresji, eksperymentowania i gry w zmienną tożsamość, a zarazem traktowania „Wszystkożerności” jako strategii adaptacyjnej wobec ambiwalencji nowoczesności ${ }^{9}$. Gdy nowoczesność pozostawia jednostce wolność w sferze konsumpcji, a zarazem pozbawia ją tradycyjnych kotwic tożsamości w postaci trwałych wspólnot - klasy, lokalności, miejsca pracy czy patriarchalnej rodziny ${ }^{10}$ - cały ciężar utrzymania spójnego „ja” spoczywa na jednostce. Rewersem wolności konsumpcyjnej jest egzystencjalny

${ }^{4}$ R.A. Peterson, A. Simkus, How musical tastes mark occupational status groups, [w:] Cultivating Differences: Symbolic Boundaries and Making of Inequality, red. M. Lamont, M. Fournier, Chicago 1992, s. 152-168; R.A. Peterson, R.M. Kern, Changing highbrow taste: from snob to omnivore, „American Sociological Review” 61, 1996, nr 5, s. 900-907.

${ }^{5}$ R. A. Peterson, Problems in comparative research: The example of omnivorousness, „Poetics” 33, 2005, nr 5-6, s. 257-282.

${ }^{6}$ Por. H. Domański, Omnivorism of eating and „highbrow - lowbrow” distinction: Cultural stratification in Poland, „Polish Sociological Review” 199, 2017, nr 3, s. 299-313. Jednym z wyjątków są badania S. Grodnego, J. Gruszki i K. Łuczaja, wskazujące na zawężanie się gustu (przynajmniej jeśli chodzi o gust muzyczny): eidem, O zawężeniu wyższego gustu estetycznego. Analiza zjawiska wszystkożerności kulturowej w Polsce, „Studia Socjologiczne” 209, 2013, nr 2, s. 127-148.

${ }^{7}$ M. Cebula, Współczesne formy kulturowych zróżnicowań. Przypadek „wszystkożerności”, „Forum Socjologiczne” 4, 2013, s. 111-131.

8 A. Warde, L. Martens, W. Olsen, Consumption and the problem of variety: Cultural omnivorousness, social distinction and dining out, „Sociology” 33, 1999, nr 1, s. 106-107.

9 Z. Bauman, Wolność, przeł. J. Tokarska-Bakir, Kraków 1995.

${ }^{10}$ Por. U. Beck, Społeczeństwo ryzyka. W drodze do innej nowoczesności, przeł. S. Cieśla, Warszawa 2002. 
lęk i niepewność własnego miejsca w społecznej hierarchii, wobec których praktyką zaradczą staje się kultywowanie wielu linii wyborów, smaków, próbowania „wszystkiego”, co może przynieść zysk symboliczny i co zaświadcza o kompetencji, horyzontach i umiejętności nieustannego uczenia się. Brak zdecydowania nie świadczy już o braku wiedzy i ogłady, lecz staje się wartością samoistną, synonimem wyrafinowania, aktywności i ambicji ${ }^{11}$.

Według innej interpretacji szerokość gustów i rozległość aktywności w żaden sposób nie podważa tezy o klasowym charakterze konsumpcji a nawet hierarchii kulturowej, stanowi bowiem nowoczesną odsłonę niewidzialnej „walki” o prestiż i wyróżnienie. Symboliczna innowacyjność, umiejętność przekraczania granic stylistycznych, kulturowa dezynwoltura stanowią formę kapitału kulturowego, funkcjonalną dla życia w płynnym, postfordystycznym uniwersum. Badacze O. Lizardo i S. Skiles ${ }^{12}$ konceptualizują „wszystkożerność” w duchu teorii P. Bourdieu ${ }^{13}$ jako współczesny wariant dyspozycji estetycznej, nabywanej w specyficznych warunkach klasowych (wolności od ograniczeń ekonomicznych), wzmacnianej w praktyce i przekładalnej na wiele dziedzin kultury. Rysem kulturowym klasy dominującej (a zwłaszcza jej frakcji najbardziej zasobnej w kapitał kulturowy) jest zdolność postrzegania obiektów prototypowo kulturowych (jak dzieła sztuki) w sposób zawieszający wszelkie oczekiwania utylitarne, to jest dążący do ekstrakcji czystej formy od funkcji i drugorzędnych elementów przedstawieniowych, co ma odzwierciedlać całościową filozofię życia tej klasy — „wolność od konieczności ekonomicznych" i swobodę kształtowania kultury. W odpowiednich warunkach makrospołecznych (opisywanych na przykład jako postmodernistyczna kultura obfitości i nadmiaru) dyspozycja estetyczna znajduje wyraz w „zawłaszczaniu” i symbolicznym opanowywaniu szerokiego repertuaru obiektów i praktyk kulturowych (włączając w to słabiej skanonizowane obszary kultury, jak muzyka, film, moda czy kuchnia). Przy takiej interpretacji wszystkożerność nie tylko nie kłóci się z tezą P. Bourdieu o klasowości praktyk kulturowych, lecz pozwala także wyjaśnić paradoks rzekomej demokratyzacji konsumpcji. Mieszanie gatunków i zaskakujące wybory klas uprzywilejowanych (na przykład powrót do prostoty i tradycji) stanowią de facto zasłonę dymną przed niewidzialną (gdyż dotyczącą stylu) „walkę” o status, której sedno tkwi w autonomizacji sposobu konsumowania od tego, co jest konsumowane. Konsekwencją takiego ujęcia „wszystkożerności” są pewne przewidywania empiryczne: wszystkożerność powinna dotyczyć wielu dziedzin życia, wiązać się z większą kompetencją kulturową i znawstwem, dotyczyć głównie osób o ponadprzeciętnym kapitale kulturowym i tych, którzy wcześnie nabyli odpowiednich schematów postrzegania

11 A. Warde, L. Martens, W. Olsen, op. cit., s. 120.

12 O. Lizardo, S. Skiles, Reconceptualizing and theorizing "omnivorousness": Genetic and relational mechanisms, „Sociological Theory” 30, 2012, nr 4, s. 263-282.

13 P. Bourdieu, Dystynkcja. Społeczna krytyka władzy sądzenia, przeł. P. Biłos, Warszawa 2005. 
i uznania (na przykład wywodzących się ze środowisk inteligenckich). W zgodzie z takim obrazem konsumenta „wszystkożernego” pozostają te dane, które wskazują, że wszystkożerność nie oznacza lubienia wszystkiego i bezwarunkowej tolerancji (mimo dominującego dyskursu o kosmopolityzmie i otwartości), lecz jedynie umiejętność „doceniania” wielu form kulturowych przy jednoczesnym odrzuceniu tego, co najbardziej zrutynizowane, spopularyzowane i umasowione (co trudno poddaje się wtórnej estetyzacji czy ironicznemu odczytaniu) ${ }^{14}$. Wciąż centralnym elementem gustu wszechstronnego pozostaje zainteresowanie tradycyjnie konsekrowanymi obiektami kultury.

W związku z tym „wszystkożerność” może być zarówno środkiem autoafirmacji w sytuacji zwielokrotnionej niepewności, jak i nieuświadamianym sposobem zaznaczania pozycji w strukturze społecznej. Nie bez znaczenia jest również ten wątek, który wiąże wszechstronność z kompetencją komunikacyjną i z nawigowaniem w rozległych sieciach relacji. Współczesne badania z pogranicza socjologii kultury i sieci społecznych wskazują bowiem na niezaprzeczalną relację między wielkością i heterogenicznością sieci osobistych kontaktów a heterogenicznością praktyk, wiedzy i preferencji kulturowych ${ }^{15}$. Partycypowanie $\mathrm{w}$ wielu dziedzinach kultury zwiększa szanse komunikowania się z przedstawicielami różnych grup społecznych, zgodnie z założeniem, że treści kulturowe stanowią potężną ogniskową dla rytuałów konwersacyjnych oraz niewerbalny sygnał powinowactwa habitusów ${ }^{16}$. Jednocześnie kompetencja komunikacyjna i umiejętność budowania kapitału społecznego same zwrotnie przyczyniają się do umacniania pozycji społecznej. Gust konsumpcyjny jest tu zarówno pierwotnym czynnikiem budowania relacji, jak i elementem kształtowanym w ich wyniku.

Celem artykułu jest wielowymiarowe spojrzenie na fenomen wszystkożerności: zarówno jako potencjalny obszar ujawniania dystynkcji klasowych, jak i czynnik warunkujący (lub warunkowany) kapitałem społecznym. Stawiane pytania badawcze dotyczą tego, w jakim stopniu „wszystkożerność” wiąże się ze wskaźnikami pozycji społecznej i statusu oraz jaką rolę w jego wyjaśnieniu odgrywają zmienne sieciowe (na przykład liczba połączeń, ich zróżnicowanie, charakter więzi i kręgów społecznych czy dostęp do zasobów kulturowych). Ten ostatni aspekt ma na celu wzbogacenie wiedzy o wzorach kultury i ich strukturotwórczej roli. Jednocześnie

${ }^{14}$ Por. A. Warde, D. Wright, M. Gayo-Cal, Understanding cultural omnivorousness: Or the myth of the cultural omnivore, „Cultural Sociology” 1, 2007, nr 2, s. 143-164; W. Atkinson, The context and genesis of musical tastes: Omnivorousness debunked, Bourdieu buttressed, „Poetics” 39, 2011, nr 3, s. 169-186.

15 B.H. Erickson, Culture, class, and connections, „American Journal of Sociology” 102, 1996, nr 1, s. 217-251; P. DiMaggio, Classification in Art, "American Sociological Review” 52, 1987, nr 4, s. 440-455; O. Lizardo, How cultural tastes shape personal networks, „American Sociological Review" 71, 2006, nr 5, s. 778-807.

${ }^{16}$ K. Puetz, Consumer culture, taste preferences, and social network formation, „Sociology Compass" 9, 2015, nr 6, s. 438-449. 
podejmując zagadnienie konsumpcji żywieniowej, artykuł rozszerza obszar badań nad stratyfikacją kulturową na dziedzinę rzadziej problematyzowaną socjologicznie (w odróżnieniu od tak zwanego uczestnictwa w kulturze), a zarazem silnie udyskursowioną i nośną symbolicznie.

\section{Klasa a wzory jedzenia}

Dynamicznie rozwijająca się obecnie socjologiczna refleksja nad jedzeniem podkreśla ten aspekt pozyskiwania, przygotowywania i spożywania żywności, który wiąże je $\mathrm{z}$ określonym kontekstem społeczno-kulturowym. Jedzenie jest praktyką na wskroś społeczną, gdyż nakierowaną i modyfikowaną w swoim przebiegu przez wartości kulturowe, normy, wyobrażenia oraz obecność innych ludzi ${ }^{17}$. Jedzenie (praktyki, preferencje, style, wzory zaopatrzenia) jako przedmiot zainteresowania socjologów stanowi źródło wiedzy o rodzinie, sieciach społecznych, wzorach kultury, aspiracjach, tożsamości, a nawet o światopoglądzie czy politycznych afiliacjach. Istotnym wątkiem jest ten wskazujący, że poprzez praktyki żywieniowe broni się i ustanawia klasowe dystynkcje oraz że jedzenie splecione jest $\mathrm{z}$ klasowym poczuciem wartości i niechęci ${ }^{18}$. Mimo iż spożywanie żywności poddawane jest presji stylizacji i indywidualizacji, a oferta gastronomiczna znacznie się poszerzyła za sprawą procesów komodyfikacji i globalizacji, nadal to, co, gdzie i jak jest spożywane, zależy od miejsca w strukturze społecznej. Kwestią sporną pozostaje co najwyżej konkretny wzór relacji łączącej pozycję społeczną z gustem i praktykami. Przykładowo badacze brytyjscy, W. Atkinson i Ch. Deeming ${ }^{19}$, dowodzili, że systematycznym odchyleniom w zakresie pozycji klasowych odpowiadają odchylenia w zakresie wydatków żywnościowych tak, że przestrzeń żywieniowa we współczesnej Wielkiej Brytanii dzieli się i nakłada na przestrzeń klas zdefiniowanych przez ilość i strukturę kapitału w sposób zbliżony do tego udokumentowanego przez Bourdieu w Dystynkcji ${ }^{20}$. To, co „lekkie” i „ekskluzywne” (klasa dominująca), przeciwstawia się temu, co „tanie i sycące” (klasa niższa), a „bogate” i „drogie” (frakcja ekonomiczna klasy wyższej), temu, co „chude” i „zdrowe” (frakcja zasobna w kapitał kulturowy). Nowością w badaniach brytyjskich było zwrócenie uwagi na etyczny wymiar konsumpcji i jego prawdopodobną rolę w ustanawianiu przemocy symbolicznej. Otóż wyposażeni w kapi-

${ }^{17}$ F. Bylok, Społeczne aspekty konsumpcji żywności - socjologiczna perspektywa, „Handel Wewnętrzny" 372, 2018, nr 1, s. 5-16.

${ }_{18}$ M. Flemmen, J. Hjellbrekke, V. Jarness, Class, culture and culinary tastes: Cultural distinctions and social class divisions in contemporary Norway, „Sociology” 52, 2017, nr 1, s. 129.

19 W. Atkinson, Ch. Deeming, Class and cuisine in contemporary Britain: the social space, the space of food and their homology, „The Sociological Review” 63, 2015, nr 4, s. 876-896.

20 P. Bourdieu, op. cit., s. 224-243. 
tał kulturowy członkowie klasy dominującej częściej kierowali się przy wyborze żywności takimi kwestiami, jak: dobro zwierząt, ekologia czy uczciwy handel, dając tym samym wyraz umiejętności opanowania modnych dyskursów, zdolnych na zasadzie opozycji ustanawiać praktyki zdominowanych jako „gorsze”, gdyż naznaczone interesownością i „wulgarnym” praktycyzmem zaspokojenia głodu w możliwie najbardziej ekonomiczny sposób ${ }^{21}$.

Choć badania P. Bourdieu są obowiązkowym punktem odniesienia dla badaczy wzorów kultury kulinarnej, część z nich jest skłonna poszukiwać nowych form dystynkcji, w których szerokość gustów i otwartość na nowości przejmują funkcję symboliczną od tradycyjnej kuchni wykwintnej (na przykład francuskiej). A. Warde, L. Martens i W. Olsen pokazali, że doświadczenie różnorodności kuchni świata (jadanie w restauracjach o różnym profilu) jest funkcją statusu socjoekonomicznego. Jednocześnie ich badania rzucają nowe światło na omawiane zagadnienie. Okazało się, że nie każda wszystkożerność ma wartość statusową, lecz ta związana z kuchniami „etnicznymi” (chińską/tajską, hinduską, włoską itp.), dającymi powab egzotyki, wyrafinowania czy kosmopolityzmu rozumianego jako zdolność do adaptacji w dowolnym kontekście i jako kulturowa tolerancja ${ }^{22}$. Obraz ten uzupełniają dane z badania replikacyjnego z 2015 roku (20 lat po pierwotnym pomiarze). Od tego czasu zasięg restauracji „etnicznych” znacznie się poszerzył, o czym świadczy spadek odsetka osób, które nie jadały w przybytkach tego rodzaju w ciągu ostatnich dwunastu miesięcy (z 48 do $22 \%)^{23}$. Mimo to badanie ujawniło silne podziały klasowe, szczególnie między stabilną klasą usługową a stabilną klasą pracującą. Pierwszą z nich wyróżniała większa częstotliwość jadania poza domem, szerokość doświadczeń kulinarnych, jadanie tego, co rzadkie (jak kuchnia wegetariańska, tajska, japońska, hinduska) i ekskluzywne (kuchnia francuska) oraz wszystkożerność, definiowania jako uczestniczenie w różnych stylach konsumpcji (popularnym, niepopularnym, ekskluzywnym). O ile więc klasa usługowa ma dostęp do doświadczeń kulinarnych klasy pracującej, o tyle ta ostatnia odcięta jest od świata gustu klasy wyższej. Jednocześnie to raczej młodsi i lepiej wyedukowani reprezentanci klasy średniej byli skłonni zwracać się w swoich wyborach ku temu, co nowe i niezwyczajne, w odróżnieniu od starszych pokoleń, przywiązanych do tradycyjnych emblematów wysokiego statusu (na przykład nowoczesnej kuchni brytyjskiej i francuskiej) $)^{24}$.

Choć "kosmopolityzm” i „egzotyka” wydają się „powszechnikami” kulinarnych doświadczeń klas uprzywilejowanych, to jednocześnie można dostrzec

${ }^{21}$ Podobną zależność odnotowano w badaniach polskich, por. M. Cebula, Konsumpcja społecznie zakorzeniona? Klasa, kapitał społeczny a wzory jedzenia, „Konsumpcja i Rozwój” 21, 2017, nr 4, s. $62-67$.

22 A. Warde, L. Martens, W. Olsen, op. cit., s. 122-123.

23 A. Warde, J. Whillans, J. Paddock, The allure of variety: Eating out in three English cities, 2015, „Poetics” 2018, s. 6, https://doi.org/10.1016/j.poetic.2018.09.001.

${ }^{24}$ Ibidem, s. 7. 
nowe, zaskakujące źródła różnic symbolicznych, w postaci powrotu do tego, co autentyczne, swojskie, czy regionalne. Przykładowo badacze norwescy opisywali klasę wyższą nie tylko jako bardziej nastawioną zdrowotnie, lecz także skłonną sięgać po tradycyjną kuchnię chłopską (na przykład wędzony łosoś, klopsiki, owsianka, brukiew) ${ }^{25}$. W gruncie rzeczy nie jest to wcale sprzeczne z myślą P. Bourdieu. Obejmowanie i przywłaszczanie nowych elementów kulturowych lub readaptacja „starych” są kluczowymi cechami „gustu wolności” klasy dominującej, wyrazem ich kompetencji i symbolicznej supremacji, które mogą stwarzać pozory, że różnice klasowe zanikają.

Przykład ten pokazuje pułapkę reifikacji, to jest przypisywania z góry wartości symbolicznej przedmiotom i zachowaniom (na przykład wysokiego statusu kuchni francuskiej) bez odwołania do systemu relacji, rekonstruowanych indukcyjnie. To, co w danym systemie społecznym jest dystynktywne, jest każdorazowo określone na mocy systematycznych zestawień - podobieństw i różnic obiektów i postaw, odniesionych następnie do systemu pozycji klasowych.

Te ostatnie możemy rozumieć za P. Bourdieu jako miejsca w przestrzeni społecznej wyznaczone przez relacje sił i przewag wynikających z opanowania różnych kapitałów: ekonomicznego, kulturowego i społecznego ${ }^{26}$. Teoria klas Bourdieu wydaje się szczególnie przydatna do analiz kulturowych, gdyż wskazuje na związek między klasową lokacją a przyjmowanymi za oczywiste sposobami postrzegania, myślenia i działania w świecie (dyspozycjami habitusu ${ }^{27}$. Pojęcie klasy nie wyczerpuje się więc w pojęciu stosunków ekonomicznych, lecz obejmuje także złożone procesy kulturowe. Ustanawianie i obrona granic klasowych odbywa się nieustannie w sferze praktyk i gustów składających się na style życia oraz w sferze dyskursów, w których zajmowanie pozycji zaświadcza o tożsamości i odrębności ${ }^{28}$. Koncepcja Bourdieu pokazuje, jak możliwe są klasowe style życia, bez obecności świadomości klasowej w marksowskim sensie.

Przyjmując taką perspektywę, niniejszy artykuł bada fenomen kulinarnej wszystkożerności w społeczeństwie polskim. Dotychczas prowadzone badania dają podstawy do przyjęcia tezy o klasowej naturze (przynajmniej niektórych) praktyk i orientacji jedzeniowych, na przykład przedstawiciele klas średnich i wyższych częściej jadają poza domem, mają bogatsze doświadczenia kulinarne, częściej eksperymentują ze smakami, są mniej tradycjonalistyczni, a bardziej przywiązani do formy posiłków (na przykład sposobu serwowania potraw) czy też kwestii

${ }^{25}$ M. Flemmen, J. Hjelbrekke, V. Jarness, op. cit., s. 12, 16.

${ }^{26}$ P. Bourdieu, op. cit., s. 132-166.

27 A. Mrozowicki, Od proletariatu do prekariatu? Doświadczenie klasy w biografiach robotników $i$ młodych pracowników sprekaryzowanych w Polsce, [w:] Klasy w Polsce. Teorie, dyskusje, badania, konteksty, red. M. Gdula, M. Sutowski, Warszawa 2017.

${ }^{28}$ M. Gdula, Pożytki z klasowości. Klasy w Polsce i szanse zmiany społecznej, [w:] Klasy w Polsce... s. $145-148$. 
etycznych i zdrowotnych ${ }^{29}$. Odnośnie do gotowania zwrócono uwagę na skłonność klasy średniej do doskonalenia własnych umiejętności, poszukiwania nowych doznań, wpisujących się w dyspozycję do indywidualizmu, podczas gdy klasie ludowej bliskie było ujęcie gotowania jako praktyki nakierowanej na innych, nie zaś na własny smak czy potrzeby (dyspozycja familiarności) ${ }^{30}$. Wszystkożerność definiowana jako próbowanie różnych, mniej lub bardziej „egzotycznych”, potraw i jako lubienie tychże jest szczególną domeną wyższych menedżerów i specjalistów oraz właścicieli, w przeciwieństwie do robotników czy rolników ${ }^{31}$. Co więcej, przesunięcie ku omniworyzmowi nie unieważnia „klasycznego” podziału na potrawy „wykwintne” i „popularne”, jako że „wszystkożercy” są jednocześnie tymi, którzy częściej spożywają dania „ekskluzywne”. Nowym elementem w wyjaśnianiu wszechstronności konsumpcyjnej był kapitał społeczny. Rozległe sieci relacji kształtują (lub są kształtowane) przez zróżnicowane preferencje kulturowe.

Proponowany w artykule model wyjaśniania wszechstronności kulinarnej dodaje nowe argumenty do debaty na temat wszystkożerności i zróżnicowań klasowych. Stara się nie tylko określić, czy wszystkożerność jest powiązana z miejscem w przestrzeni społecznej, lecz także które praktyki kulinarne są szczególnie dystynktywne oraz jakie właściwości sieci społecznych (na przykład zróżnicowanie, charakter relacji) regulują szerokość repertuaru?

\section{Dane i metody}

Podstawą analiz empirycznych są dane uzyskane w sondażu zrealizowanym w 2017 roku na reprezentatywnej próbie $(\mathrm{N}=1010)$ dorosłych mieszkańców Wrocławia, w wieku 18-75 lat, przy użyciu metody indywidualnych wywiadów wspomaganych komputerowo (CAPI). Sondaż był elementem projektu badawczego finansowanego ze środków Narodowego Centrum Nauki, mającego na celu wielowymiarowe spojrzenie na związek między pozycją społeczną, sieciami powiązań a gustem i praktykami konsumpcyjnymi i kulturowymi ${ }^{32}$. Kwestionariusz wywiadu obejmował szerokie spektrum zagadnień dotyczących stylu życia, w takich dziedzinach, jak: telewizja, film, sztuka, muzyka, czas wolny, wakacje, korzystanie z internetu itp. obok pytań na temat relacji społecznych (na przykład liczby kontaktów, wsparcia społecznego, kręgów społecznych, intensywności kontaktów) i cech społeczno-demograficznych (w tym pozycji klasowej).

${ }^{29}$ H. Domański et. al., Wzory jedzenia a struktura społeczna, Warszawa 2015; M. Cebula, Konsumpcja społecznie zakorzeniona...; idem, Czy klasy społeczne się liczą? O (nie)przydatności analiz klasowych dla potrzeb marketingu, „Marketing i Rynek” 2015, nr 3, s. 9-19.

${ }^{30}$ M. Gdula, M. Lewicki, P. Sadura, Praktyki kulturowe klasy ludowej, Warszawa 2014, s. 46.

${ }^{31}$ H. Domański, Omnivorism of eating..., s. 307-311.

32 Projekt nr 2016/21/D/HS6/02424 pt. „Struktura społeczna, sieci społeczne a gust i praktyki konsumpcyjne". 
Jednym z poruszanych tematów był gust kulinarny oraz zakres doświadczeń żywieniowych. Badanych pytano o to, które potrawy/produkty (z przedstawionej listy) zdarzyło im się spróbować przynajmniej raz w swoim życiu ${ }^{33}$ oraz jakie przyprawy/składniki wykorzystuje się w ich gospodarstwach domowych ${ }^{34}$. Liczba pozytywnych wskazań utworzyła indeks wszystkożerności, przyjmujący wartości od 0 do 18. Warto zaznaczyć, że proponowany wskaźnik odzwierciedla zakres doświadczeń kulinarnych, ciekawość i tylko do pewnego stopnia indywidualny gust $^{35}$. Tak zbudowaną zmienną konfrontowano następnie ze zmiennymi socjodemograficznymi i sieciowymi, z których najważniejsze to: pozycja klasowa (podział na wyższe kadry kierownicze i specjalistów; techników, pracowników umysłowych średniego szczebla; pracowników handlu i usług; drobnych przedsiębiorców i samozatrudniających się; sprzedawców, robotników i niewykwalifikowanych pracowników usług ${ }^{36}$ ), wykształcenie, zamożność gospodarstwa ${ }^{37}$, liczba połączeń (kontaktów) mierzona tak zwanym generatorem pozycji, liczba relacji w podziale na członków rodziny, przyjaciół i znajomych, zróżnicowanie sieci oraz dostęp do osób wpływających na styl życia (szacowany za pomocą tak zwanego generatora zasobów). W odróżnieniu od poprzednich badań ${ }^{38}$ zestaw wskaźników sieciowych jest tu znacznie poszerzony.

Jak wskazano, wszystkożerność może być elementem budowania kompetencji komunikacyjnej i „nawigowania” w sieciach relacji, co kieruje nas w stronę teorii kapitału społecznego. Mimo rozlicznych interpretacji terminu jego podstawą jest to, że aktorzy społeczni (indywidualni lub zbiorowi) mogą osiągać określone korzyści, realizować cele lub być biernymi biorcami efektów z tytułu społecznych powiązań, uczestnictwa w strukturach społecznych i przynależności grupowej ${ }^{39}$. Elementami kapitału są: sieci powiązań, zasoby innych dostępne dzięki nim, ale także normy i zaufanie, regulujące wzajemne działania. Założono, że wszystkożerność będzie tym większa, im badany: a) ma większą liczbę trwałych kontaktów, b) obejmujących

${ }^{33}$ Lista obejmowała następujące pozycje: crème brûlée, guacamole (pasta z awokado), krewetki, szparagi, risotto, ser mascarpone, ślimaki, bakłażan.

${ }^{34}$ Lista obejmowała takie pozycje, jak: świeża bazylia, rukola, jarmuż, oliwki zielone, świeża kolendra, curry, suszone pomidory, imbir (suszony lub świeży), zioła prowansalskie, gotowa mieszanka typu vegeta.

${ }^{35} \mathrm{~Np}$. próbowane potrawy, produkty niekoniecznie musiały być tymi najbardziej lubianymi. Jeśli chodzi o przyprawy używane w kuchni, prawdopodobieństwo ich związku z preferencjami jest wyższe.

${ }^{36}$ Za podstawę klasyfikacji przyjęto społeczną klasyfikację zawodów: H. Domański, Z. Sawiński, K.M. Słomczyński, Nowa klasyfikacja i skale zawodów. Socjologiczne wskaźniki pozycji społecznej w Polsce, Warszawa 2007.

37 Zamożność gospodarstwa szacowano na podstawie liczby posiadanych dóbr, takich jak: zmywarka do naczyń, smartfon, przenośny komputer, ekspres ciśnieniowy do kawy, sprzęt sportowy, samochód itp. (w sumie 11 pozycji).

${ }^{38}$ Por. H. Domański, Omnivorism...

39 Por. N. Lin, Social Capital. A Theory of Social Structure and Action, Cambridge 2001, s. 21-25. 
bardziej zróżnicowane osoby (na przykład pod względem cech demograficznych i kulturowych), oraz c) im te kontakty są bardziej rozległe (to jest wykraczające poza najbliższy krąg społeczny rodziny) i d) obejmujące osoby, które są źródłem wsparcia, codziennych informacji i inspiracji w zakresie stylu życia.

Liczbę połączeń szacowano między innymi za pomocą generatora pozycji ${ }^{40}$, pytając respondenta, czy zna osoby (wśród rodziny, przyjaciół lub znajomych), które wykonują określone zawody lub zajmują określone pozycje społeczne ${ }^{41}$. Przyjmuje się, że większy kapitał społeczny jest udziałem tych osób, które mają więcej „znajomości” lub/i „znajomości” o potencjalnie dużych zasobach (czego przybliżeniem jest pozycja społeczna kontaktu) ${ }^{42}$. Przez zróżnicowanie sieci należy rozumieć to, w jakim stopniu sieć składa się z osób różniących się od ego, na przykład pod względem cech demograficznych czy też kulturowych. Respondentów proszono o odpowiedź, czy wśród ich przyjaciół i bliskich znajomych są osoby, które na przykład różnią się od nich wiekiem o co najmniej 15 lat, mają inne poglądy polityczne, znacznie różnią się statusem materialnym, preferują inny rodzaj muzyki, literatury, rozrywki, prowadzą inny tryb życia itp. Pozytywna odpowiedź na te pytania składała się na wyższą wartość indeksu zróżnicowania ${ }^{43}$.

Dla oszacowania rozległości kontaktów, to jest ich społecznego zasięgu, respondentów proszono o podanie przybliżonej liczby osób, z którymi utrzymują oni regularnie (przynajmniej kilka razy w roku) kontakty towarzyskie lub osobiste. Dla ułatwienia zadania szacowanie to odbywało się sekwencyjnie, w podziale na poszczególne kręgi społeczne, to jest osoby z rodziny (powyżej 12. roku życia, niezamieszkałe $\mathrm{z}$ respondentem), przyjaciół (spoza rodziny), znajomych (na przykład z miejsca pracy, z miejsca zamieszkania, szkoły itp.) ${ }^{44}$.

Ostatnia ze zmiennych sieciowych - dostęp do osób wpływających na styl życia i partnerów konwersacyjnych - została ujęta z perspektywy tak zwanego generatora zasobów ${ }^{45}$. Za jego pomocą ocenia się, czy osoba badana ma dostęp do kontaktów charakteryzujących się określonymi umiejętnościami, czy też zasobami. W omawianym badaniu zadawano pytanie: „Czy wśród członków Pana(i) rodziny

${ }^{40}$ Ibidem.

${ }^{41}$ Lista obejmowała następujące zawody: prawnik, lekarz, pracownik naukowy wyższej uczelni, nauczyciel, informatyk, przedsiębiorca/właściciel firmy (inny niż pracodawca), lokalny polityk, dziennikarz, mechanik, księgowy/a, artysta/aktor/muzyk, kasjer/sprzedawca, pielęgniarka/pielęgniarz, pracownik budowlany lub robót wykończeniowych. Wskaźnik przyjmował wartości od 0 do 14 .

42 P.V. Marsden, Survey Methods for Network Data, [w:] The SAGE Handbook of Network Analysis, red. J. Scott, P.J. Carrington, London 2012, s. 377-379.

${ }^{43}$ Odpowiedzi na osiem pytań mierzono na skali 4-punktowej, gdzie 1 oznaczało „raczej nie” a 4 - „tak, wiele osób”. Punkty następnie sumowano. Utworzona zmienna przyjmowała wartości od 8 do 32.

${ }^{44}$ Podobną metodologią posługiwał się O. Lizardo (op. cit., s. 789).

${ }^{45}$ M. van der Gaag, T.A.B Snijders, The Resource Generator: social capital quantification with concrete items, „Social Networks” 27, 2005, nr 1, s. 1-29. 
lub przyjaciół, znajomych są na przykład osoby, z którymi można porozmawiać o ważnych sprawach osobistych; osoby, z którymi można porozmawiać o sprawach codziennych typu: rodzina, dzieci, praca, obowiązki domowe lub wymienić się poradami; osoby, które są źródłem informacji, jak można ciekawie spędzić czas, co zobaczyć, gdzie wyjechać?" itp. W sumie uwzględniono sześć pytań, na których pozytywne odpowiedzi zagregowano.

\section{Rezultaty}

Do najpopularniejszych (najbardziej rozpowszechnionych) potraw, produktów i składników kulinarnych należały: szparagi (z którymi zetknęło się $76 \%$ respondentów), ser mascarpone (72,7\%), zioła prowansalskie (71,6\%) i bakłażan (71,5\%). Z kolei ślimaki były zdecydowanie rzadszym elementem doświadczenia kulinarnego $(27,7 \%)$, podobnie jak modny ostatnio jarmuż $(34,9 \%)$, crème brûlée (37,9\%) czy mająca powab egzotyki - świeża kolendra (41,2\%). Brak danych porównawczych nie pozwala rozstrzygnąć, jak bardzo gust kulinarny Polaków zmienił się w ciągu ostatnich kilkudziesięciu lat. Niewątpliwie jednak za sprawą procesów globalizacji, utowarowienia i udyskursowienia jedzenia zakres tego, co możliwe w kuchni (lub choćby sama świadomość możliwości), znacznie się poszerzyły. Nie oznacza to jednak, że procesy dyfuzji działają równomiernie. Już pobieżna analiza ujawnia związek między próbowaniem lub stosowaniem niektórych produktów a położeniem klasowym. Nawet w przypadku dość spopularyzowanych szparagów możemy dostrzec społeczny dystans między przedstawicielami wyższych kadr kierowniczych i inteligencji, z których $87 \%$ próbowało ten produkt, a pracownikami handlu i usług czy robotnikami do prac prostych i niewykwalifikowanymi pracownikami usług — takich osób było odpowiednio 69 i 67,9\%. Uwiarygodnia to tezę, że szerokość kulinarnego „obycia” jest funkcją społeczno-ekonomicznego statusu.

Aby bliżej zbadać tę zależność, indeks wszystkożerności (wszechstronności) kulinarnej poddano analizie regresji liniowej, w której predyktorami zmiennej zależnej były cechy społeczno-demograficzne oraz sieciowe respondentów. W kolejnych krokach analizy dodawano poszczególne zestawy czynników, tak aby oszacować ich niezależny udział w wyjaśnianiu wszystkożerności (tabela 1).

Zgodnie z przypuszczeniem sama pozycja klasowa objaśniała łącznie 10,8\% wariancji zmiennej zależnej po skorygowaniu, pokazując przewagę wyższych kadr i specjalistów nad sprzedawcami, robotnikami i niewykwalifikowanymi pracownikami usług (model I). Zarazem wpływ klasy zanikał w momencie wprowadzenia do modelu zmiennych demograficznych (jak wiek, płeć czy wielkość gospodarstwa) oraz stratyfikacyjnych, to jest wykształcenia i zamożności (model II). Przypuszczalnie wpływ klasy jest zapośredniczony przez kapitał kulturowy i ekonomiczny, które zgodnie z koncepcją P. Bourdieu stanowią główne czynniki strukturalizujące przestrzeń społeczną. 
Tabela 1. Wszystkożerność kulinarna a pozycja klasowa i sieci społeczne (wyniki analizy regresji liniowej $j^{\mathrm{a}}$ )

\begin{tabular}{|c|c|c|c|}
\hline Zmienne (predyktory) & Model I & Model II & Model III \\
\hline (Stała) & $-* * *$ & $-* * *$ & - \\
\hline wyższe kadry kierownicze, specjaliści & $0,234^{\star \star *}$ & 0,027 & $-0,007$ \\
\hline technicy, pracownicy umysłowi średniego szczebla & $0,125^{\star}$ & $-0,004$ & $-0,035$ \\
\hline pracownicy handlu i usług & ref. & ref. & ref. \\
\hline drobni przedsiębiorcy i samozatrudniający się & 0,065 & 0,058 & 0,045 \\
\hline $\begin{array}{l}\text { sprzedawcy, robotnicy i niewykwalifikowani } \\
\text { pracownicy usług }\end{array}$ & $-0,156^{* *}$ & $-0,042$ & $-0,040$ \\
\hline płeć (kobieta) & & $0,078^{\star}$ & $0,071^{*}$ \\
\hline wiek & & $-0,126^{\star * *}$ & $-0,070^{*}$ \\
\hline wykształcenie & & $0,312^{* * *}$ & $0,236^{* * *}$ \\
\hline zamożność gospodarstwa & & $0,070^{*}$ & $0,085^{\star}$ \\
\hline 1 osoba w gospodarstwie domowym & & ref. & ref. \\
\hline 2 osoby w gospodarstwie domowym & & 0,018 & $-0,015$ \\
\hline 3 osoby w gospodarstwie domowym & & 0,053 & $-0,002$ \\
\hline 4 lub więcej osób w gospodarstwie domowym & & $0,155^{\star *}$ & 0,080 \\
\hline liczba połączeń (generator pozycji) & & & $0,115^{\star *}$ \\
\hline liczba kontaktów towarzyskich: rodzina & & & $0,084^{*}$ \\
\hline liczba kontaktów towarzyskich: przyjaciele & & & 0,032 \\
\hline liczba kontaktów towarzyskich: znajomi & & & $0,176^{\star * *}$ \\
\hline zróżnicowanie sieci & & & $0,089^{* *}$ \\
\hline $\begin{array}{l}\text { dostęp do osób wpływających na styl życia } \\
\text { (generator zasobów) }\end{array}$ & & & $0,163^{* * *}$ \\
\hline skorygowane $\mathrm{R}^{2}$ & 0,108 & 0,222 & 0,360 \\
\hline $\begin{array}{l}\text { statystyki zmiany (w porównaniu do modelu } \\
\text { poprzedniego) }\end{array}$ & - & $\begin{array}{l}\Delta F(7,798) \\
=17,782 \\
p<0,001\end{array}$ & $\begin{array}{l}\Delta \mathrm{F}(6,792) \\
=29,782 ; \\
\mathrm{p}<0,001\end{array}$ \\
\hline
\end{tabular}

a współczynniki standaryzowane (beta)

${ }^{*} \mathrm{p}<0,05 \quad{ }^{* *} \mathrm{p}<0,01 \quad{ }^{* * *} \mathrm{p}<0,001$

Źródło: opracowanie własne na podstawie badań mieszkańców Wrocławia. 
W żadnej mierze nie podważa to twierdzenia o pozycyjnym uwarunkowaniu orientacji kulinarnych. Warto zauważyć, że to głównie wykształcenie, a w znacznie mniejszym stopniu sytuacja finansowa, decyduje o rozległości jedzeniowych doświadczeń. Pozostaje to w zgodzie z hipotezą O. Lizarda i S. Skiles ${ }^{46}$, doszukujących się we wszystkożerności współczesnej manifestacji dyspozycji estetycznej, charakteryzującej przede wszystkim ponadprzeciętnych posiadaczy zasobów kulturowych. Dość wspomnieć, że dodatkowa analiza wskazywała, iż skłonność do rozszerzania repertuaru kulinarnego jest tym większa, im wyższe było wykształcenie rodziców (stanowiące tutaj wskaźnik „atmosfery kulturalnej” domu; współczynnik korelacji $r$ Pearsona =0,239; $\mathrm{p}<0,001)$, choć jednocześnie wpływ pochodzenia słabł niemal do zera przy uwzględnieniu edukacji respondenta, silnie zależnego od statusu rodziców. W zgodzie z innymi ustaleniami także wiek wiązał się $\mathrm{z}$ orientacją na wszystkożerność ${ }^{47}$. Młodsi badani (choć nie najmłodsi) deklarowali zdecydowanie większą liczbę próbowanych potraw i stosowanych przypraw (średnio 11,3 przy odchyleniu standardowym równym 4,06 w grupie 26-35 lat) niż ich starsi (65+) odpowiednicy $(\mathrm{M}=8,03 ; \mathrm{SD}=4,93)$. Przypuszcza się, że wpływ wieku odzwierciedla tak zwany efekt kohortowy, czyli ogólne przesunięcie we wzorach kultury wywołane odmiennym zestawem doświadczeń socjalizacyjnych osób urodzonych w różnym czasie ${ }^{48}$. Młodsi badani, wychowani w okresie otwierania się polskiego społeczeństwa na trendy zachodnie i przenikania kultur w globalizującym się świecie, mieli więcej sposobności przyswojenia nowych smaków i stylów życia niż dorastający w gospodarce niedoborów.

Nie jest zaskoczeniem, że kobiety, z racji swoich ról społecznych, znały więcej potraw i składników kulinarnych (średnio 10,3 wobec 9,2 dla mężczyzn). Wielkość gospodarstwa domowego (ale niekoniecznie liczba posiadanych dzieci) również miała pozytywny wpływ na wszechstronność. Być może większa liczba osób w najbliższym otoczeniu zwiększa szanse na wzbogacenie własnego repertuaru smaków, co wskazywałoby na rolę kapitału społecznego.

Znaczenie tego ostatniego było szacowane w modelu III, uwzględniającym różne wymiary osobistych sieci społecznych. Istotna zmiana jakości dopasowania modelu regresji $(\Delta \mathrm{F})$ oraz wielkości skorygowanego $\mathrm{R}^{2}(\mathrm{z} 0,222$ do 0,360$)$ informują nas, że zmienne sieciowe są dodatkowym (i niezależnym) elementem wyjaśniającym „wszystkożerność”. Okazuje się, że jest ona tym większa, im większa jest liczba deklarowanych połączeń w generatorze zasobów (beta $=0,115$; $\mathrm{p}<0,01)$ oraz im są one bardziej zróżnicowane - odległe od cech ego (beta $=0,084 ; \mathrm{p}<0,05)$. Co ważne jednak, nie każdy rodzaj relacji ma równą wagę. Utrzymywanie rozległych więzi ze znajomymi (o których można przypuszczać,

\footnotetext{
46 O. Lizardo, S. Skiles, op. cit.

47 M. Cebula, Czy klasy społeczne się liczą?... s. 17.

48 Por. R.A. Peterson, R.M. Kern, op. cit., s. 900-907.
} 
że tworzą słabe połączenia w rozumieniu M. Granovettera ${ }^{49}$ ), bardziej przekłada się na uczestniczenie $\mathrm{w}$ wielu kulinarnych światach aniżeli więzi rodzinnych czy przyjacielskich. Teoria sieci wskazuje, że słabsze połączenia są częściej tak zwanymi pomostami, spinającymi oddalone od siebie rejony przestrzeni społecznej. Siła słabych więzi bierze się właśnie stąd, że stanowią one cenne źródło informacji niedostępnych w najbliższym kręgu społecznym. Jeśli potraktować kontakty jako źródło tego, co nowe i nieznane, to osoby utrzymujące relacje z wieloma osobami (do tego z innymi od niej samej) są szczególnie predestynowane, aby nabywać złożone zasoby wiedzy i kompetencji ${ }^{50}$. Nie wyklucza to odwrotnej zależności. Biegłość i szerokie zainteresowania w wielu obszarach kultury umożliwiają komunikowanie się z wieloma osobami, budowanie ram tożsamości i tworzenie tą drogą społecznego kapitału ${ }^{51}$. Nie sam fakt istnienia więzi przesądza jeszcze o szansach na wszystkożerność, lecz także ich „zawartość” (dostęp do zasobów). Otóż obecność w otoczeniu jednostki osób, z którymi można porozmawiać o ważnych lub codziennych sprawach, które są źródłem informacji, gdzie ciekawie spędzić czas, co nowego dzieje się w „kulturze”, czego warto spróbować, znacznie przekłada się na wszechstronność kulinarną (beta $=0,163 ; \mathrm{p}<0,001$ ). Badacze praktyk jadania poza domem pokazywali, że rozmowy na temat własnych doświadczeń jedzeniowych (odwiedzanych miejsc czy smaków) były powszechnym zjawiskiem w społeczeństwie brytyjskim, choć jednocześnie bardziej typowym dla reprezentantów wyższej klasy średniej. Uogólniając, można stwierdzić, że doświadczenia kulinarne są cenną walutą na rynku relacji towarzyskich i prestiżu: pozwalając na autoprezentację własnych kompetencji, wiedzy i kosmopolitycznych horyzontów ${ }^{52}$.

Dotychczasowe ustalenia pokazują, iż wzór wszystkożerności pełni co najmniej dwie funkcje w systemie społecznym: oznaczania granic klasowych i kulturowych oraz uczestniczenia w budowaniu kapitału społecznego. Czy jednak wszystkie elementy repertuaru kulinarnego są w tym względzie równoważne? Czy może tylko niektóre z nich odgrywają szczególną, symboliczną rolę? ${ }^{53}$

W celu eksploracji tego zagadnienia obliczono współczynniki korelacji pomiędzy próbowaniem lub używaniem określonego dania/składnika kulinarnego a zmiennymi stratyfikacyjnymi - wykształceniem i zamożnością gospodarstwa $^{54}$. Wielkości współczynników potraktowano jako współrzędne punktów w dwuwymiarowej przestrzeni (rys. 1). Punkty znajdujące się blisko wartości „0" oznaczają, iż konsumpcja określonej potrawy lub przyprawy w niewiel-

${ }^{49}$ M.S. Granovetter, The strength of weak ties, „American Journal of Sociology” 78, 1973, nr 6, s. $1360-1380$.

${ }^{50}$ B.H. Erickson, op. cit. s. 217-251.

${ }^{51}$ O. Lizardo, op. cit., s. 778-807.

52 A. Warde, L. Martens, W. Olsen, op. cit., s. 121-122.

${ }^{53}$ Ibidem, s. 116.

${ }^{54}$ Wykorzystano współczynnik Eta, przyjmujący wartości od 0 do 1. 
kim stopniu zależy od cech położenia społecznego. Dla rozstrzygnięcia, który składnik lub danie bardziej zależy od kapitału kulturowego (wykształcenia), a który od ekonomicznego, przez środek układu współrzędnych przeprowadzono linię 45 stopni. Punkty znajdujące się powyżej linii (to jest po lewej stronie) wskazują na większą wagę kapitału ekonomicznego a znajdujące się poniżej kulturowego. W większości wypadków (za wyjątkiem gotowej mieszanki przypraw typu vegeta) wartość współczynników wskazuje jednocześnie na kierunek zależności.

Możemy zauważyć, że szczególnie dystynktywne (ze względu na wykształcenie i zamożność) było próbowanie takich potraw, jak crème brûlée, ślimaki, krewetki, guacamole, czy też wykorzystywanie w kuchni świeżej kolendry, z kolei zioła prowansalskie czy gotowa mieszanka przypraw w znacznie mnieszym stopniu wiązały się z pozycją społeczną (miały mniejszą moc różnicującą). Dodatkowo rozmieszczenie punktów w przestrzeni wskazuje, iż to kapitał kulturowy (mierzony wykształceniem) ma większe znaczenie w wyjaśnianiu doświadczenia kulinarnego. Mówiąc inaczej, przy zbliżonym poziomie zamożności tym, co decyduje o próbowaniu potraw lub stosowaniu przypraw, jest kompetencja kulturowa (przypuszczalnie wiedza o kuchniach świata, składnikach i sposobach ich używania oraz komponowania, wyczucie stylu).

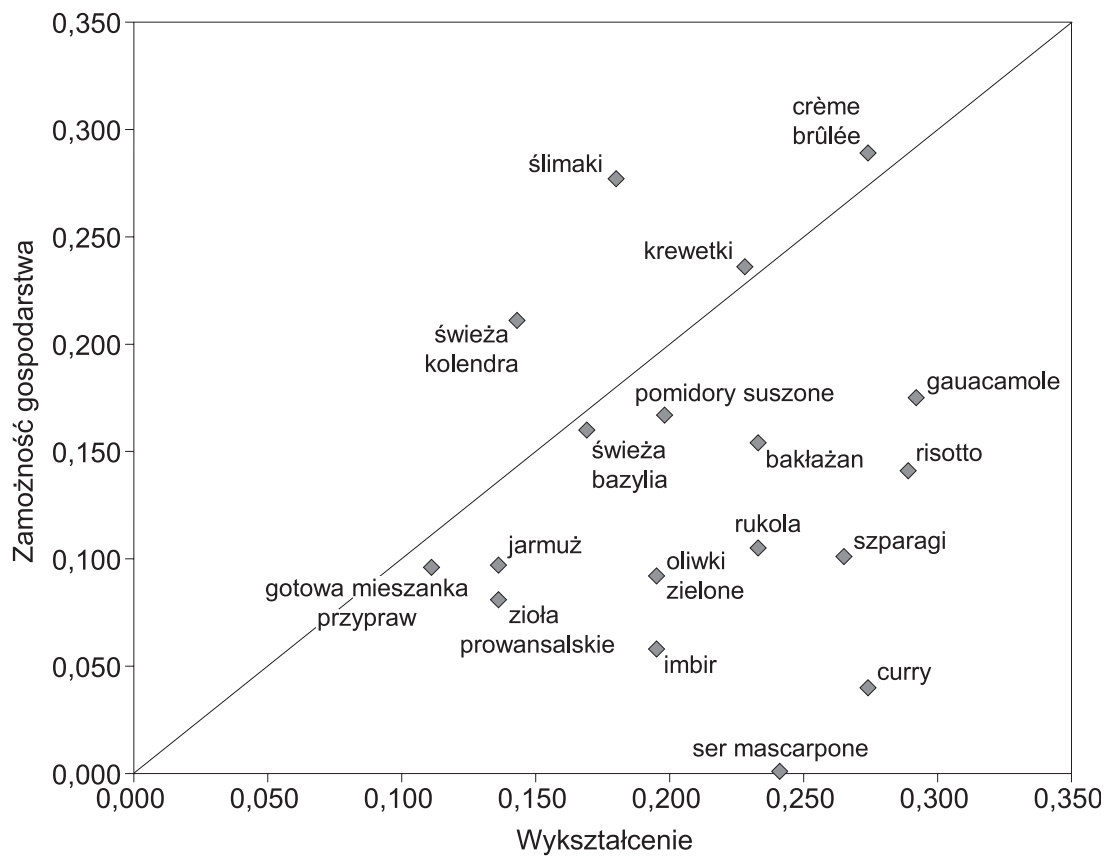

Wykres 1. Próbowanie lub używanie produktów a wykształcenie i zamożność gospodarstwa

Źródło: opracowanie własne na podstawie badań mieszkańców Wrocławia. 
Szczególnym przypadkiem jest tutaj ser mascarpone, którego spożycie zupełnie nie zależało od czynnika finansowego. $Z$ kolei próbowanie ślimaków w większej mierze wiązało się z wyższym statusem ekonomicznym gospodarstwa. Nie musi to wynikać $\mathrm{z}$ ceny potrawy, ale z tego, że określone doświadczenie kulinarne jest udziałem osób o różnym profilu kapitałowym. Zgodnie z teorią P. Bourdieu gust różnicuje się zarówno według ogólnej ilości kapitału, jak i jego struktury (co pokazuje podziały frakcyjne na poziomie konkretnych klas) ${ }^{55}$. Najsilniej (dodatnio) z wykształceniem korelowały: guacamole, risotto, crème brûlée oraz curry, reprezentujące różne tradycje kulinarne. Jak wiemy z modelu regresji, to wykształcenie w największym stopniu wyjaśnia wszechstronność smaków i szerokość kulinarnego repertuaru.

Aby pogłębić zrozumienie symbolicznej roli produktów, w dalszej analizie wzięto pod uwagę dwa przypadki: risotto oraz gotową mieszankę przypraw typu vegeta, sytuujące się po przeciwnych stronach przestrzeni konsumpcji. Ogólnie w badanej próbie wskazane danie włoskie próbowało kiedykolwiek w swoim życiu 59,8\% osób, jednakże odsetek ten był wyższy lub niższy w zależności od wielu zmiennych. Prawdopodobieństwo spróbowania dania rosło do 92,3\% dla osób, które: utrzymywały kontakty towarzyskie z więcej niż dziewięcioma znajomymi, należały do kategorii społeczno-zawodowej co najmniej pracowników handlu i usług (lub wyższej) i których zróżnicowanie sieci oszacowano na poziomie powyżej 15,50 (na skali 8-32, przy średniej dla próby wynoszącej 16,3). Z kolei utrzymywanie relacji z mniej niż dziewięcioma znajomymi, zdobycie wykształcenia poniżej policealnego lub pomaturalnego, przynależność do grupy wiekowej powyżej 49,5 lat oraz osób o niższym niż przeciętne zróżnicowaniu sieci zmniejszało omawiane prawdopodobieństwo do $22,6 \%$. Z tego zestawienia wynika, że prawdopodobieństwo pewnych doświadczeń kulinarnych nie jest równo dystrybuowane w społeczeństwie i zależy od wielu cech demograficznych i stratyfikacyjnych (szczególnie od parametrów sieci: liczby znajomych, zróżnicowania kontaktów, wieku i wykształcenia, traktowanych jako czynniki względnie niezależne).

Stosowanie gotowej mieszanki przypraw było jedyną zmienną negatywnie skorelowaną z wykształceniem i zamożnością gospodarstwa i znamionowało raczej osoby o niższym statusie. Choć w całej próbie odsetek respondentów deklarujących użycie tego składnika wynosił 62,7, to jednocześnie był wyższy (95,6\%) wśród tych, którzy: byli drobnymi przedsiębiorcami lub robotnikami, należącymi co najwyżej do jednej organizacji pozarządowej i o kapitale rodzinnym poniżej $-1,4$ odchylenia standardowego od średniej. Mówiąc inaczej, im niższe było wykształcenie rodziców, niższy formalny kapitał społeczny (przynależność do organizacji) i niższa pozycja zawodowa, tym większe prawdopodobieństwo używania mieszanki przypraw w kuchni. Z kolei przynależność do grupy studiującej młodzieży, pracowników handlu i usług, techników i pracowników umysłowych

${ }^{55}$ P. Bourdieu, op. cit. s. 222-243. 
średniego szczebla lub wyższych kadr kierowniczych i specjalistów, a do tego przynależność do co najmniej 1 lub 2 organizacji, zmniejszało prawdopodobieństwo stosowania gotowych mieszanek do $38,6 \%$.

Uogólniając, zetknięcie się lub używanie określonych składników żywieniowych zależy od miejsca w strukturze społecznej oraz od relacji społecznych. W stosunku do osób o szerszych i bardziej zróżnicowanych sieciach istnieje większe prawdopodobieństwo zyskiwania nowych doświadczeń kulinarnych, próbowania nowych dań i stosowania niestandardowych przypraw (zapewne dzięki dyfuzji informacji czy wpływowi normatywnemu).

\section{Podsumowanie i dyskusja}

Eksponowany w literaturze wątek „wszystkożerności” kulturowej wydaje się strategią konsumpcji szczególnie dobrze skrojoną na współczesne czasy. Będąc odpowiedzią na poczucie niepewności wynikające $\mathrm{z}$ ambiwalencji nowoczesności, wszystkożerność pełni jednocześnie funkcję manifestowania kompetencji komunikacyjnej oraz podtrzymywania klasowych dystynkcji. Te dwie ostatnie funkcje były przedmiotem zainteresowania $\mathrm{w}$ niniejszym artykule, podejmującym wątek społecznych aspektów jedzenia. Powołując się na P. Bourdieu, można argumentować, że wśród różnych obszarów stylizacyjnych gust związany z jedzeniem wydaje się szczególnie interesujący, gdyż dotyka kwestii smaku w jego najbardziej podstawowej, literalnej i znaturalizowanej postaci. Kontekstem badań było przypuszczenie, iż w dobie postępującej globalizacji, komodyfikacji i estetyzacji jedzenia różnice klasowe będą ustępować miejsca różnicom wynikającym $\mathrm{z}$ indywidualnych wyborów stylu życia. To założenie nie znalazło potwierdzenia w danych. Wszechstronność doświadczeń i zachowań kulinarnych ściśle wiąże się z miejscem w strukturze społecznej, będąc domeną osób o ponadprzeciętnym kapitale kulturowym, zajmujących uprzywilejowane pozycje zawodowe, lepiej sytuowanych materialnie i młodych (co może wskazywać na pewną zmianę pokoleniową). Jednocześnie można zauważyć, że wszystkożerność nie oznacza bezwarunkowej tolerancji wszelkich dóbr i stylów, lecz koncentruje się raczej wokół tego, co egzotyczne, zdrowe, wykwintne, świeże czy też autentyczne (na przykład ślimaki, risotto, crème brûlée, curry, guacamole, świeża kolendra i inne zioła) przy jednoczesnym dystansie do tego, co „masowe” i „pospolite” (a także „nieautentyczne") jak gotowa mieszanka przypraw typu vegeta. W tym sensie nie podważa to teorii P. Bourdieu, który w zdolności do estetycznej ekspansji znajdował wyraz symbolicznej supremacji klasy dominującej. Warto dodać, że style życia i wybory dokonywane $\mathrm{w}$ jego ramach stanowią wyraz niewidzialnej i niewyrozumowanej walki o uznanie, godność i dominację i uwikłane są w moralne dyskursy na temat zdrowia, ekologii, dobrostanu zwierząt, natury itp. o potencjalnie wykluczającym charakterze. Wybory klas niższych, jak wspomniane przyprawy, mogą w związku 
z tym być odczytywane jako skażone grzechem „łatwości”, „konserwatyzmu”, „dogadzania sobie kosztem zdrowia" itp.

Nowym wątkiem $\mathrm{w}$ prezentowanym badaniu był ten dotyczący funkcjonalności „wszystkożerności” wobec kapitału społecznego. Potwierdzono, że rozległość doświadczeń kulinarnych idzie w parze z ogólną wielkością sieci, jej zróżnicowaniem czy dostępem do osób będącym „nośnikiem” informacji i nowych idei. Co więcej, różnorodność prawdopodobnie łączy się z posiadaniem słabych połączeń (typu znajmościowego), które, zgodnie z teorią sieci, tworzą pomosty umożliwiające cyrkulację wiedzy pomiędzy oddalonymi rejonami przestrzeni społecznej. Choć dane nie pozwalają bezpośrednio wnioskować o zależności między repertuarem kulinarnym a relacjami społecznymi, można przypuszczać, że rozmowy o jedzeniu stanowią ważny składnik aktywności towarzyskich, swoisty wyraz symbolicznej konsumpcji, w której przejawiają się wiedza, kompetencje, tożsamość. Jedzenie jest także bezpośrednim działaniem społecznym (wówczas gdy jest okazją do spotkań).

Jakkolwiek badanie rzuca nowe światło na społeczne aspekty jedzenia, niektóre kwestie wciąż wymagają pogłębienia. Dotyczy to sposobów konsumowania (a nie tylko tego, co jest konsumowane), śledzenia relacji przyczynowej pomiędzy gustem a sieciami (na przykład jak wiedza kulinarna jest dystrybuowana w kontaktach albo też jak służy ich budowaniu) czy monitorowania zmian w czasie (czy wszystkożerność umacnia się jako wzór kulturowy).

\section{Bibliografia}

Atkinson W., The context and genesis of musical tastes: Omnivorousness debunked, Bourdieu buttressed, „Poetics” 39, 2011, nr 3.

Atkinson W., Deeming Ch., Class and cuisine in contemporary Britain: the social space, the space of food and their homology, „The Sociological Review” 63, 2015, nr 4.

Bauman Z., Wolność, przeł. J. Tokarska-Bakir, Kraków 1995.

Beck U., Społeczeństwo ryzyka. W drodze do innej nowoczesności, przeł. S. Cieśla, Warszawa 2002.

Bourdieu P., Dystynkcja. Społeczna krytyka władzy sądzenia, przeł. P. Biłos, Warszawa 2005.

Bylok F., Społeczne aspekty konsumpcji żywności - socjologiczna perspektywa, „Handel Wewnętrzny" 372, 2018, nr 1.

Cebula M., Czy klasy społeczne się liczą? O (nie)przydatności analiz klasowych dla potrzeb marketin$g u$, „Marketing i Rynek” 2015, nr 3.

Cebula M., Konsumpcja społecznie zakorzeniona? Klasa, kapitał społeczny a wzory jedzenia, „Konsumpcja i Rozwój” 21, 2017, nr 4.

Cebula M., Społeczne uwarunkowania gustów i praktyk konsumpcyjnych. Zbieżność pozycji społecznych i stylów życia czy autonomizacja kultury?, „Studia Socjologiczne” 209, 2013, nr 2.

Cebula M., Współczesne formy kulturowych zróżnicowań. Przypadek „wszystkożerności”, „Forum Socjologiczne" 4, 2013.

Chan T.W., Goldthorpe J.H., Social stratification and cultural consumption: Music in England, „European Sociological Review" 23, 2007, nr 1.

DiMaggio P., Classification in art, „American Sociological Review” 52, 1987, nr 4. 
Domański H., Omnivorism of eating and "highbrow - lowbrow” distinction: Cultural stratification in Poland, „Polish Sociological Review” 199, 2017, nr 3.

Domański H., Karpiński Z., Przybysz D., Straczuk J., Wzory jedzenia a struktura społeczna, Warszawa 2015.

Domański H., Sawiński Z., Słomczyński K.M., Nowa klasyfikacja i skale zawodów. Socjologiczne wskaźniki pozycji społecznej w Polsce, Warszawa 2007.

Erickson B.H., Culture, Class, and Connections, „American Journal of Sociology” 102, 1996, nr 1.

Flemmen M., Hjellbrekke J., Jarness V., Class, culture and culinary tastes: Cultural distinctions and social class divisions in contemporary Norway, „Sociology” 52, 2017, nr 1.

Gaag M. van der, Snijders T.A.B., The resource generator: Social capital quantification with concrete items, „Social Networks” 27, 2005, nr 1.

Gdula M., Pożytki z klasowości. Klasy w Polsce i szanse zmiany społecznej, [w:] Klasy w Polsce. Teorie, dyskusje, badania, konteksty, red. M. Gdula, M. Sutowski, Warszawa 2017.

Gdula M., Lewicki M., Sadura P., Praktyki kulturowe klasy ludowej, Warszawa 2014.

Granovetter M.S., The strength of weak ties, „American Journal of Sociology” 78, 1973, nr 6.

Grodny S., Gruszka J., Łuczaj K., O zawężeniu wyższego gustu estetycznego. Analiza zjawiska wszystkożerności kulturowej w Polsce, „Studia Socjologiczne” 209, 2013, nr 2.

Holt D.B., Does cultural capital structure American consumption?, „Journal of Consumer Research" 25, 1998, nr 1 .

Lin N., Social Capital. A Theory of Social Structure and Action, Cambridge 2001.

Lizardo O., How cultural tastes shape personal networks, „American Sociological Review” 71, 2006, nr 5.

Lizardo O., Skiles S., Reconceptualizing and theorizing "omnivorousness": Genetic and relational mechanisms, „Sociological Theory” 30, 2012, nr 4.

Marsden P.V., Survey Methods for Network Data, [w:] The SAGE Handbook of Network Analysis, red. J. Scott, P.J. Carrington, London 2012.

Mrozowicki A., Od proletariatu do prekariatu? Doświadczenie klasy w biografiach robotników i młodych pracowników sprekaryzowanych w Polsce, [w:] Klasy w Polsce. Teorie, dyskusje, badania, konteksty, red. M. Gdula, M. Sutowski, Warszawa 2017.

Peterson R.A., Problems in comparative research: The example of omnivorousness, „Poetics” 33, 2005, nr 5-6.

Peterson R.A., Kern R.M., Changing highbrow taste: from snob to omnivore, „American Sociological Review" 61, 1996, nr 5.

Peterson R.A., Simkus A., How musical tastes mark occupational status groups, [w:] Cultivating Differences: Symbolic Boundaries and Making of Inequality, red. M. Lamont, M. Fournier, Chicago 1992.

Prieur A., Savage M., Updating cultural capital theory: A discussion based on studies in Denmark and in Britain, „Poetics” 39, 2011, nr 6.

Puetz K., Consumer culture, taste preferences, and social network formation, „Sociology Compass” 9, 2015, nr 6.

Veblen T., Teoria klasy próżniaczej, przeł. J. Frentzel-Zagórska, Warszawa 2008.

Warde A., Martens L., Olsen W., Consumption and the problem of variety: Cultural omnivorousness, social distinction and dining out, „Sociology” 33, 1999, $\mathrm{nr} 1$.

Warde A., Whillans J., Paddock J., The allure of variety: Eating out in three English cities, 2015, „Poetics", 2018, https://doi.org/10.1016/j.poetic.2018.09.001.

Warde A., Wright D., Gayo-Cal M., Understanding cultural omnivorousness: Or the myth of the cultural omnivore, „Cultural Sociology” 1, 2007, nr 2. 


\section{Variety of culinary tastes: On distinctive and communicative facets of eating}

\section{Summary}

The bulk of the contemporary debate in cultural stratification research refers to the concept of omnivorousness. According to it, the stratification of tastes in modern societies resembles an inverted pyramid separating higher social classes with broad tastes cutting across the fine and popular genres at the top from lower social classes with narrow tastes at the bottom. The aim of the article is to shed light on this phenomenon by inferring the social and symbolic significance of the variety of food experience. The omnivorousness presents people with opportunities for demonstrating communicative competence and for staking claims to social exclusivity. Based on a large survey into the exposure to a variety of foods, spices and ingredients, this article shows that omnivorosusness is a function of socio-economic position, although the relationship gets stronger as specific items are considered. Furthermore, the culinary repertoire depends on personal network characteristics such as size, diversity, access to resources and type of social relation. The celebration of variety makes it possible to operate in the postmodern world of diverse commodities and styles and to communicate with people of different cultural profiles. 